\title{
PENGENDALIAN DAN PENJAMINAN MUTU PENGAJARAN MELALUI SUPERVISI KLINIS
}

\author{
Anggriati Ledu Ngaba \\ 942016028@student.uksw.edu \\ Program Studi Magister Manajemen \\ FKIP - Universitas Kristen Satya Wacana \\ Anggit Ginanjar P \\ 942016014@student.uksw.edu \\ Program Studi Magister Manajemen \\ FKIP - Universitas Kristen Satya Wacana \\ Erfy Melany Lalupanda \\ 942016031@student.uksw.edu \\ Program Studi Magister Manajemen \\ FKIP - Universitas Kristen Satya Wacana \\ Sherly Istika Sari \\ 942016005@student.uksw.edu \\ Program Studi Magister Manajemen \\ FKIP - Universitas Kristen Satya Wacana
}

\begin{abstract}
ABSTRAK
Tujuan penelitian ini adalah untuk meningkatkan mutu pengajaran guru melalui supervisi klinis. Penelitian ini adalah penelitian tindakan sekolah dengan menggunakan pendekatan deskriptif kuantitatif. Penelitian dilakukan pada salah satu sekolah dasar di Kabupaten Semarang. Pengumpulan data menggunakan: (1) studi dokumentasi, (2) observasi, dan (3) wawancara. Hasil penelitian dengan analisis Quality Control ditemukan bahwa guru disekolah tersebut mengalami permasalahan dalam pengajaran, analisis Quality Assurance menghasilkan diagnosis penyebab permasalahan dalam pengajaran, analisis Quality Improvement menghasilkan tindakan yang dilakukan untuk mengatasi masalah yang dihadapi dengan melakukan supervisi klinis. Hasil supervisi klinis menunjukkan adanya peningkatan mutu pengaran yang dilakukan guru pada siklus I dan II, analisis Capacity Building bertujuan untuk memaksimalkan keberhasilan supervisi klinis yang menghasilkan program tindak lanjut yang dapat dilakukan kepala sekolah sebagai pendamping supervisi klinis yaitu melakukan teknik supervisi kelompok.
\end{abstract}

Kata kunci: pengendalian mutu, penjaminan mutu, mutu pengajaran, supervisi klinis

\section{PENDAHULUAN}

Pendidikan merupakan salah satu faktor penting yang menentukan kemajuan suatu negara. Keberhasilan pendidikan sangat ditentukan oleh guru sebagai pelaksana pembelajaran. Sekolah memiliki peran sebagai lembaga yang memproses lulusan untuk bidang-bidang pekerjaan dalam kehidupan masyarakat secara luas. Peran yang diberikan kepada sekolah adalah sebagai bentuk tanggungjawabnya untuk mencerdaskan anak 
bangsa. Oleh karena itu sekolah melaksanakan kegiatan layanan belajar sesuai dengan pp no 19 tahun 2005 pasal 1 ayat 1 yang menyatakan standar nasional pendidikan adalah kriteria minimal tentang sistem pendidikan di seluruh wilayah Negara Kesatuan Republik Indonesia. Inti dari kegiatan sekolah adalah memberi layanan belajar kepada peserta didik sesuai dengan standar minimal yang yang telah ditentukan. Pelaksanaan pendidikan perlu penjaminan mutu yang bertujuan untuk memenuhi atau melampaui standar nasional pendidikan. Salah satu hal penting yang perlu dilakukan berkaitan dengan mutu pendidikan adalah mutu layanan belajar. Artinya peserta didik mendapat layanan yang berkualitas dari sekolah dengan seluruh perangkat yang ada didalamnya yang disebut dengan layanan belajar yang berkualitas (Sagala, 2010).

Layanan yang berkualitas salah satunya ditentukan oleh kompetensi guru. Kompetensi ini berkaitan dengan kemampuan guru dalam menyiapkan proses pembelajaran seperti menyiapkan rencana pembelajaran, melakukan proses pembelajaran sampai pada evaluasi hasil belajar siswa. Kompetensi guru di indonesia masih rendah. Berdasarkan data Neraca Pendidikan 2016 nilai UKG guru SD tingkat nasional adalah 54,33, untuk daerah provinsi Jawa Tengah nilai UKG untuk guru SD adalah 61,88 dan untuk kota salatiga nilai UKG guru SD adalah 68,14. Hal ini menunjukan mutu pembelajaran yang rendah, terlebih pada aspek kompetensi pedagogik yang berkaitan langsung dengan pembelajaran di kelas.

Peningkatan kualitas pembelajaran menuju pendidikan yang lebih baik perlu dilakukan dengan upaya yang sistematis dan berkelanjutan seperti menerapkan manajemen mutu terpadu (total quality management) yang mempunyai prinsip, yaitu fokus pada kepuasan pelanggan, respek terhadap setiap orang, manajemen berdasarkan fakta, dan perbaikan berkesinambungan (Ahmad, 2017). Salah satu cara memperbaiki mutu pengajaran adalah dengan menerapkan program supervisi klinis yang dilakukan oleh pengawas atau kepala sekolah terhadap guru. Tujuan utama supervisi klinis adalah perbaikan proses belajar mengajar untuk meningkatkan mutu proses dan mutu hasil pembelajaran peserta didik. Selain itu supervisi klinis juga dapat meningkatkan kinerja guru dalam mengajar (Purwanto, 2009).

Sasaran utama supervisi klinis adalah kemampuan guru dalam merencanakan/ mempersiapkan kegiatan pembelajaran, melaksanakan kegiatan pembelajaran, menilai hasil pembelajaran, memanfaatkan hasil penilaian untuk peningkatan layanan pembelajaran, menciptakan lingkungan belajar yang menyenangkan, memanfaatkan sumber belajar yang tersedia, dan mengembangkan interaksi pembelajaran antara peserta didik dan guru (strategi, metode, teknik) yang tepat. Supervisi klinis diharapkan dapat meningkatkan kualitas pembelajaran, peserta didik akan terlayani secara baik untuk meningkatkan kemampuan sesuai potensinya, serta meningkatkan prestasi dan persentase lulusan dari satuan lembaga pendidikan (Purwanto, 2009). Pendapat tersebut sejalan dengan hasil penelitian I Wayan Korma (2012) di SD Gugus IV Kecamatan Denpasar Selatan yang menunjukkan bahwa ada pengaruh yang signifikan dari implementasi supervisi klinis secara simultan terhadap wawasan kompetensi pedagogik dan kualitas pengelolaan pembelajaran. Hal serupa juga ditunjukkan dalam penelitian yang dilakukan oleh Yusni Siregar (2016) di SMPN Kecamatan Medang Deras Kabupaten Batu Bara yang bertujuan untuk meningkatkan kinerja guru melalui supervisi klinis. Hasil penelitian menunjukkan bahwa ada peningkatan kinerja guru dalam hal 
penyusunan perangkat pembelajaran, perencanaan kegiatan pembelajaran, dan penilaian pembelajaran IPA di SMP Negeri Kecamatan Medang Deras pada siklus I dan siklus II.

Berdasarkan hasil observasi dan wawancara terhadap guru dan kepala sekolah, guru di SD Negeri Rowosari secara administrasi sudah mempersiapkan rencana pembelajaran. Namun proses pembelajaran tidak sesuai dengan perencanaan, guru jarang menerapkan pembelajaran PAKEM sehingga mempengaruhi kualitas pembelajaran. Berdasarkan hal tersebut, peneliti ingin menerapkan supervisi klinis untuk meningkatkan mutu pengajaran. Hasil penelitian ini diharapkan dapat memberikan sumbangan pemikiran terhadap pengembangan pelaksanaan supervisi klinis dalam rangka meningkatkan kompetensi pedagogik guru. Secara praktis, dapat menjadi umpan balik dan masukan kepala sekolah untuk melaksanakan supervisi secara terprogram dan terstruktur, meningkatkan motivasi guru untuk menjadi tenaga pengajar yang profesional, dan dapat digunakan oleh pihak terkait sebagai pedoman penyusunan strategi dalam peningkatan mutu sekolah.

\section{KAJIAN PUSTAKA}

\section{Mutu Pengajaran}

Mutu pengajaran sangat ditentukan oleh kompetensi yang dimiliki oleh guru itu sendiri. Mutu guru dalam mengajar pada hakekatnya merupakan interaksi dari berbagai faktor yang mempengaruhinya, yaitu faktor yang datang dari dalam dan luar diri guru. Faktor dari dalam antara lain kesehatan, potensi dan kemampuan diri, bakat, sikap dan kepribadian. Sedangkan faktor yang berasal dari luar antara lain faktor kepemimpinan kepala sekolah, peserta didik dan sarana prasarana.

Guru yang bermutu adalah guru yang profesional. Profesionalisme guru di Indonesia mengacu pada UU Nomor 14 Tahun 2005 tentang guru dan dosen, yaitu 1) memenuhi syarat kualifikasi akademik yaitu memiliki latar belakang pendidikan yang memadai dan relevan dengan bidang ajarnya; dan 2) menguasai empat kompetensi guru yaitu: kompetensi pribadi, pedagogik, profesional dan sosial (Andriani, 2009). Standar Nasional Pendidikan pasal 28 ayat (3) butir menyatakan bahwa yang dimaksud dengan kompetensi pedagogik adalah kemampuan mengelola pembelajaran peserta didik meliputi pemahaman terhadap peserta didik, perancangan dan pelaksanaan pembelajaran, evaluasi hasil belajar, dan pengembangan peserta didik untuk mengaktualisasi ragam potensi yang dimilikinya.

Kompetensi pedagogik merupakan kemampuan guru dalam melakukan pengelolaan pembelajaran di kelas, yang meliputi aspek-aspek: (a) pemahaman wawasan dan landasan kependidikan, (b) pemahaman terhadap peserta didik, (c) pengembangan kurikulum/silabus, (d) perancangan pembelajaran, (e) pelaksanaan pembelajaran yang mendidik dan dialogis, (f) pemanfaatan teknologi pembelajaran, (g) evaluasi hasil belajar (EHB), dan (h) pengembangan peserta didik untuk mengaktualisasikan berbagai potensi yang dimilikinya (Balqis dkk, 2014).

\section{Supervisi Klinis}

Muslim (2009) menyebutkan bahwa guru merupakan suatu profesi yang sedang tumbuh. Lebih lanjut dijelaskan bahwa sebagai suatu profesi, guru tentu harus bekerja secara profesional. Guna mendukung peran tersebut, guru dituntut memiliki kualifikasi dan kompetensi yang memadai untuk membimbing peserta didik dalam melakukan proses pembelajaran. Guru juga dituntut untuk mengembangkan kompetensi pedagogiknya untuk dapat mengatasi berbagai masalah atau 
persoalan pembelajaran di kelas. Peningkatan proses atau kualitas pembelajaran ini dianggap penting, karena berdampak langsung terhadap peserta didik sebagai hasil pendidikan. Salah satu upaya yang dapat dilakukan dalam proses peningkatan dan pengembangan kompetensi pedagogik guru yaitu melalui kegiatan pengawasan atau supervisi. Supervisi secara umum memberikan hal positif baik bagi guru maupun kepala sekolah. Bagi guru kegiatan supervisi dapat mengurai berbagai masalah yang terjadi selama pembelajaran di kelas. Bagi kepala sekolah dapat meninjau atau menilai langsung proses pembelajaran yang terjadi dikelas dan dapat saling bertukar pikiran berkaitan demi kemajuan kualitas. Berkaitan dengan istilah acuan yang dipakai model supervisi dibagi menjadi empat bentuk: a) model konvensional (tradisional), b) model supervisi ilmiah, dan (c) model supervisi klinis dan d) model artistik. Model yang digunakan dalam penelitian ini adalah model supervisi klinis (Achmad, 2017: 141).

Supervisi klinis merupakan salah satu jenis supervisi yang dilakukan oleh kepala sekolah terhadap guru. Jenis supervisi ini merupakan bantuan profesional yang diberikan secara sistematis kepada guru berdasarkan kebutuhan guru tersebut dengan tujuan untuk membina guru dan juga dapat meningkatkan profesionalisme dalam melaksanakan proses pembelajaran. Kepala sekolah selaku supervisor klinis selain sebagai penanggungjawab tugas-tugas supervisi klinis, juga harus melakukan akuntabilitas terhadap tugas-tugas tersebut. Dengan kata lain, jika tanggung jawab merupakan usaha agar apa yang dibebankan kepadanya dapat diselesaikan sebagaimana mestinya dalam waktu tertentu, maka akuntabilitas harus melebihi dari kewajiban itu.

Pidarta (2002:251) mengemukakan, pengertian supervisi klinik adalah clinical artinya berkenaan dengan menangani orang sakit selanjutnya, dokter mengadakan diagnosis dan resep untuk mengobati penyakit pasiennya. Sama halnya dengan mendiagnosa dalam proses belajar mengajar, untuk menemukan aspek-aspek mana yang membuat guru itu tidak dapat mengajar dengan baik. Jadi supervisi klinik merupakan satu model supervisi untuk menyelesaikan masalah tertentu yang sudah diketahui sebelumnya dengan menggunakan cara ini. Purwanto (2009: 76) mengungkapkan bahwa supervisi adalah suatu aktivitas pembinaan yang direncanakan untuk membantu para guru dan pegawai sekolah lainnya dalam melakukan pekerjaan mereka secara efektif. Supervisi dalam pendidikan bukan hanya sekadar untuk melihat apakah segala kegiatan/ aktivitas yang dilakukan telah dilaksanakan sesuai dengan rencana yang telah digariskan tetapi dapat memotivasi guru untuk melakukan pekerjaan dengan lebih baik dan menjadi alat yang efektif untuk memperbaiki kinerja guru.

Beberapa definisi tersebut, dapat disimpulan bahwa supervisi klinis adalah suatu teknik supervisi yang dilakukan oleh supervisor (kepala sekolah) untuk memberikan bantuan yang bersifat profesional yang diberikan berdasarkan kebutuhan guru yang bersangkutan dalam mengatasi masalah yang dihadapi dalam proses belajar mengajar melalui bimbingan yang intensif yang disusun secara sistematis dengan tujuan untuk meningkatkan kemampuan mengajar dan meningkatkan profesionalisme guru.

Langkah-langkah pelaksanaan supervisi klinis menurut Pidarta (2002) ada 4 langkah dalam supervisi klinis yaitu: (1) Tahap pertemuan awal atau perencanaan terdiri dari menciptakan hubungan yang baik dengan cara menjelaskan makna supervisi klinis, menemukan aspek-aspek perilaku apa dalam proses belajar mengajar yang perlu 
diperbaiki, dan membuat skala prioritas aspekaspek perilaku yang akan diperbaiki; (2) Tahap persiapan meliputi persiapan diri guru sebagai subjek supervisi dan kepala sekolah sebagai supervisor; (3) Tahap pelaksanaan yang terdiri dari pengamatan pelaksanaan pembelajaran oleh supervisor dengan memperhatikan aspek-aspek yang perlu diperbaiki; (4) Tahap pertemuan akhir meliputi tanggapan guru terhadap ulasan dari supervisor, menyimpulkan bersama hasil yang dicapai, dan menentukan rencana selanjutnya.

Sesuai dengan permasalahan yang dihadapi oleh guru sekolah dasar, yaitu masih rendahnya kompetensi pedagogik guru dalam kegiatan belajar mengajar, strategi yang digunakan untuk mengatasi masalah tersebut adalah dengan melakukan supervisi klinis. Pokok pemikiran peneliti dalam penelitian ini adalah sebagai berikut:

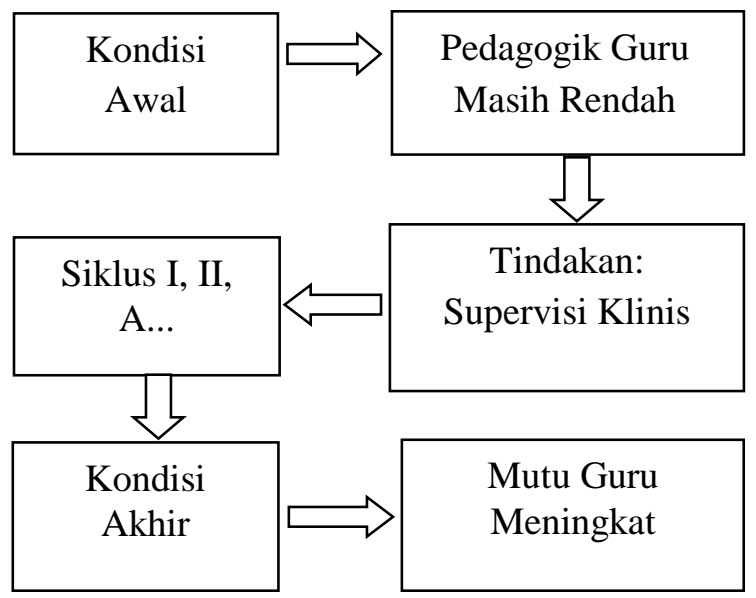

Gambar 1 Kerangka Pikir Penelitian

\section{METODE PENELITIAN}

Jenis penelitian ini adalah penelitian tindakan sekolah dengan menggunakan pendekatan deskriptif kuantitatif. Waktu penelitian Febuari-Maret 2017. Subjek penelitian adalah tiga orang guru pada salah satu sekolah dasar di Kabupaten Semarang. Pengumpulan data menggunakan studi dokumentasi, observasi, dan wawancara. Studi dokumentasi dilakukan terhadap dokumen hasil supervisi yang telah dilakukan oleh kepala sekolah, dan data hasil penilaian kinerja guru. Penilaian hasil observasi dihitung dengan menggunakan rumus dan klasifikasi berikut:

$$
\text { Rumus : Nilai }=\frac{\text { Total Skor }}{\text { Skor Maksimal }} \times 100
$$

Nilai hasil observasi tersebut kemudian diklasifikasikan dalam lima kategori sebagai berikut:

Tabel 1 Klasifikasi penilaian hasil observasi

\begin{tabular}{ccc}
\hline Interval Nilai & Kualifikasi & Keterangan \\
\hline $90-100$ & $\mathrm{~A}$ & Amat baik \\
$80-89$ & $\mathrm{~B}$ & Baik \\
$60-79$ & $\mathrm{C}$ & Cukup \\
$51-59$ & $\mathrm{D}$ & Kurang \\
$<50$ & $\mathrm{E}$ & Sangat Kurang \\
\hline
\end{tabular}

Penelitian ini menggunakan langkahlangkah manajemen perbaikan mutu menurut gorton yang meliputi identifikasi masalah, diagnosis masalah, penetapan tujuan, pembuatan keputusan, perencanaan, pengorganisasian, penginisiasian, dan penilaian.

\section{Identifikasi Masalah}

Berdasarkan hasil observasi dan wawancara terhadap guru dan kepala sekolah, guru di SD Negeri Rowosari secara administrasi sudah mempersiapkan rencana pembelajaran. Namun, dalam proses pembelajaran tidak sesuai dengan yang direncanakan dalam administrasi. Terkadang guru kurang menerapkan pembelajaran PAKEM, dan tidak jarang guru menerapkan pembelajaran ceramah. Dalam setiap akhir pembelajaran, guru jarang memberikan evaluasi terhadap siswa.

\section{Diagnosis Masalah}

Masalah pada penelitian ini didiagnosis menggunakan pohon masalah seperti gambar 2: 


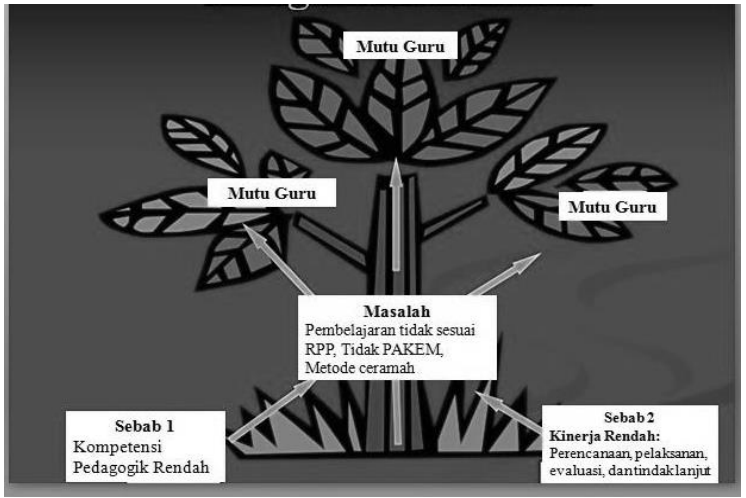

Gambar 2 Pohon Masalah

\section{Penetapan Tujuan dan Pembuatan Keputusan}

Tujuan yang ditetapkan dalam penelitian ini adalah meningkatkan mutu pengajaran guru dengan melakukan tindakan supervisi klinis.

\section{Perencanaan}

Perencanaan dalam penelitan ini adalah sebagai berikut: (1) membuat instrumen supervisi klinis; (2) menentukan subjek yang akan disupervisi; (3) mentukan waktu pelaksanaan; (4) melakukan supervisi klinis; (5) menganalisis hasil supervisi klinis; dan (6) tindak lanjut.

\section{Pengorganisasian}

Dalam penelitian ini kepala sekolah bertindak sebagai supervisor menggunakan teknik supervisi klinis. Sedangkan subjek penelitian adalah tiga orang guru. Peneliti bertindak sebagai pendamping supervisor dan observer.

\section{Penginisiasian}

Penginisiasian dilakukan dalam 2 tahap yaitu: tahap 1 merupakan tes awal untuk mengetahui kompetensi pedagogik guru sebelum dilakukan tindakan dan tahap 2 merupakan pelaksanaan supervisi klinis. Prosedur pelaksanaan supervisi klinis ada tiga tahap yaitu: (1) tahap perencanaan (tahap pertemuan awal); (2) tahap observasi mengajar, dan (3) tahap evaluasi dan analisis (pertemuan balikan). Tahap perencanaan meliputi usaha menciptakan suasana yang hangat dan bebas antara guru dengan supervisor, telaah dan diskusikan keterampilan yang akan dilatih, telaah rencana pelajaran dan cermati tujuan pelajaran dan tujuan dari latihannya mendiskusikan isi instrumen yang akan digunakan. Tahap observasi meliputi pengamatan yang dilakukan supervisor dengan cara merekam fokus kegiatan maupun interaksi yang terjadi baik antara guru dengan siswa, maupun antara siswa dengan siswa, dengan menggunakan instrumen yang telah disepakati. Tahap evaluasi dan analisis meliputi konfirmasi supervisor kepada guru tentang peranannya selama melakukan latihan mengajar, melihat kembali target keterampilan dan fokus utama latihan yang disepakati.

\section{Penilaian}

Penilaian menggunakan Strategi Penjamin Mutu melalui analisis quality control (QC), quality assurance (QA), quality improvement (QI), dan capacity building (CB).

\section{HASIL DAN PEMBAHASAN}

\section{Hasil}

Hasil penelitian berdasarkan analisis Quality Control (QC) diperoleh hasil: 1). Pelaksanaan pembelajaran tidak sesuai dengan rencana pembelajaran yang telah dibuat; 2). Guru kurang menerapkan pembelajaran PAKEM. Guru lebih menggunakan ceramah; 3). Guru jarang memberikan evaluasi terhadap siswa pada setiap akhir pmbelajaran. Analisis Quality Assurance (QA) diperoleh hasil bahwa Kemampuan mengajar guru rendah atau Kompetensi Pedagogik Guru Rendah. Analisis Quality Improvement (QI) diperoleh 
hasil bahwa untuk meningkatkan kompetensi guru, perlu dilakukannya supervisi klinis.

Prosedur pelaksanaan supervisi klinis dilakukan dengan sistem siklus yaitu pra siklus, siklus I dan siklus II. Pada kegiatan pra siklus, nilai penyusunan RPP oleh guru 1 adalah 58 berada pada kategori kurang sedangkan nilai pelaksanaan PBM adalah 68 berada pada kategori cukup. Nilai penyusunan RPP oleh guru 2 adalah 68 berada pada kategori cukup dan nilai pelaksanaan PBM adalah 73 berada pada kategori cukup. Nilai penyusunan RPP oleh guru 3 adalah 66 berada pada kategori cukup dan nilai pelaksanaan PBM adalah 75 berada pada kategori cukup.

Pelaksanaan supervisi dilakukan pada siklus I. Hasil supervisi klinis siklus I menunjukkan nilai penyusunan RPP oleh guru 1 adalah 63 berada pada kategori cukup sedangkan nilai pelaksanaan PBM adalah 70 berada pada kategori cukup. Nilai penyusunan RPP oleh guru 2 adalah 70 berada pada kategori cukup dan nilai pelaksanaan PBM adalah 75 berada pada kategori cukup. Nilai penyusunan RPP oleh guru 3 adalah 70 berada pada kategori cukup dan nilai pelaksanaan PBM adalah 76 berada pada kategori cukup.

Hasil pra siklus dan siklus 1, menunjukkan adanya peningkatan nilai pada penyusunan RPP dan pelaksanaan PBM. Namun nilai tersebut masih berkategori cukup, sehingga diperlukan adanya siklus II.

Hasil supervisi siklus II menunjukkan nilai penyusunan RPP oleh guru 1 adalah 80 berkategori baik sedangkan nilai pelaksanaan PBM adalah 83 berkategori baik. Nilai penyusunan RPP oleh guru 2 adalah 84 berkategori baik dan nilai pelaksanaan PBM adalah 86 berkategori baik. Nilai penyusunan RPP oleh guru 3 adalah 83 berkategori baik dan nilai pelaksanaan PBM adalah 85 berkategori baik. Rekapitulasi hasil supervisi klinis pra siklus, siklus I, dan siklus II, disajikan pada Tabel 2.

Tabel 2 Rekapitulasi Hasil Supervisi Klinis

\begin{tabular}{llcccccc}
\hline & & \multicolumn{2}{c}{ Pra Siklus } & \multicolumn{2}{c}{ Siklus I } & \multicolumn{2}{c}{ Siklus II } \\
\cline { 3 - 8 } No & Guru & $\begin{array}{c}\text { Menyusun Melaksanakan } \\
\text { RPP }\end{array}$ & PBM & Renyusun & Melaksanakan & Menyusun & Melaksanakan \\
& & PPP & 63 & PBM & RPP & PBM \\
\hline 1. & Guru 1 & 58 & 68 & 63 & 70 & 83 \\
2. & Guru 2 & 68 & 73 & 70 & 75 & 84 & 86 \\
3. & Guru 3 & 66 & 75 & 70 & 76 & 83 & 85 \\
\hline
\end{tabular}

\section{Pembahasan}

Pengendalian mutu atau Quality Control $(Q C)$ merupakan kegiatan yang telah melalui proses standar yang telah ditetapkan. Proses pengendalian mutu terdiri dari kegiatan mengamati, membandingkan kinerja dengan standar dan mengambil keputusan (Pasaribu, 2015). Hasil penelitian dengan memperhatikan kinerja guru dengan standar yang telah ditetapkan, menunjukkan bahwa pelaksanaan pembelajaran tidak sesuai dengan rencana pembelajaran yang telah dibuat, guru kurang menerapkan pembelajaran PAKEM, guru lebih menggunakan ceramah, dan guru jarang memberikan evaluasi terhadap siswa pada setiap akhir pembelajaran, sehingga perlu dilakukannya penjaminan mutu.

Penjaminan mutu atau Quality Assurance $(Q A)$ adalah proses penetapan dan pemenuhan standar mutu pengelolaan pendidikan secara konsisten dan berkelanjutan sehingga para stakeholders dan pihak lain yang berkepentingan mendapatkan kepuasan (Aspranawa, 2015). Penjaminan mutu Quality Assurance (QA) digunakan untuk menetapkan standar-standar mutu dari semua komponen yang bekerja dalam produksi atau transformasi lulusan yang meliputi 
pendekatan pembelajaran aktif, kolaboratif, kooperatif, konstruktif dan tuntas (Suti, 2011). Hasil penelitian menunjukkan bahwa penjaminan mutu di sekolah yang menjadi subjek penelitian, khususnya pada guru tidak dilakukan secara konsisten dan berkelanjutan sehing-ga kemampuan mengajar atau kompetensi pedagogik guru rendah yang berakibat pada rendahnya mutu pembelajaran. Proses penjaminan mutu sekolah seharusnya melibatkan pihak-pihak terkait seperti orang tua, komite sekolah, masyarakat, dan lembaga lain penerima lulusan sehingga penjaminan mutu di sekolah dapat berjalan secara maksimal. Kelanjutan proses penjaminan mutu adalah dengan melakukan perbaikan dan peningkatan.

Perbaikan dan peningkatan atau Quality Improvement (QI) merupakan proses yang dilakukan secara terus-menerus untuk menjamin semua komponen penyelenggaraan pendidikan dalam mencapai standar mutu yang telah ditetapkan dan bertujuan untuk memperbaharui proses pendidikan berdasarkan tuntutan pelanggan (Suti, 2011). Berdasarkan hasil analisis Quality Control (QC) dan Quality Assurance (QA), masalah rendahnya mutu pembelajaran di sekolah dapat diatasi dengan menerapkan supervisi klinis. Tujuan supervisi klinis adalah membantu guru melihat dengan jelas masalah yang dialami dalam proses pembelajaran, menganalisisnya secara kritis dan mendorong guru menemukan alternatif pemecahan masalah. Hasil supervisi klinis di sekolah menunjukkan peningkatan kompetensi pedagogik guru. Hal ini berarti bahwa mutu pembelajaran dapat ditingkatkan melalui supervisi klinis untuk mencapai hasil yang maksimal, perlu dilakukan pendampingan.

Pendampingan atau Capacity Building $(C B)$ dapat dimaknai sebagai proses membangun dan memperkuat kapasitas individu, kelompok, atau organisasi yang dicerminkan melalui pengembangan kemampuan, keterampilan, potensi, bakat dan penguasaan sehingga dapat bertahan dan mampu mengatasi tantangan perubahan yang terjadi secara tepat serta dapat pula dimaknai sebagai proses kreatif dalam membangun kapasitas yang belum nampak (Ratnasari dkk, 2013). Berdasarkan hasil analisis Quality Improvement $(Q I)$ dalam rangka membangun dan mengembangkan kompetensi mengajar guru secara berkelanjutan, sekolah dalam hal ini Kepala Sekolah, melaksanakan program prioritas perbaikan bagi guru, salah satunya dengan melaksanakan supervisi kelompok sebagai pendamping supervisi klinis. Supervisi kelompok ini bertujuan untuk membantu guru menyelesaikan masalah yang dihadapi secara berkelompok. Analisis strategi penjamin mutu pendidikan di sekolah secara lengkap disajikan pada Tabel 3.

Tabel 3 Hasil analisis Strategi Penjamin Mutu Pendidikan di Sekolah

\begin{tabular}{|c|c|c|c|}
\hline QC (Quality Control $)$ & $\begin{array}{l}\text { QA }(\text { Quality } \\
\text { Assurance })\end{array}$ & $\begin{array}{c}\text { QI(Quality } \\
\text { Improvement })\end{array}$ & $\begin{array}{c}C B \\
\text { (Capacity Building) }\end{array}$ \\
\hline $\begin{array}{l}\text { Pelaksanaan pembelajaran tidak sesuai } \\
\text { dengan rencana pembelajaran yang telah } \\
\text { dibuat } \\
\text { Guru kurang menerapkan pembelajaran } \\
\text { PAKEM. Guru lebih menggunakan } \\
\text { ceramah } \\
\text { Guru jarang memberikan evaluasi terhadap } \\
\text { siswa pada setiap akhir pembelajaran }\end{array}$ & $\begin{array}{l}\text { Kemampuan } \\
\text { mengajar guru } \\
\text { rendah atau } \\
\text { Kompetensi } \\
\text { Pedagogik } \\
\text { Guru Rendah }\end{array}$ & $\begin{array}{l}\text { Melakukan } \\
\text { supervisi klinis } \\
\text { untuk mening- } \\
\text { katkan kompe- } \\
\text { tensi guru }\end{array}$ & $\begin{array}{l}\text { Program prioritas } \\
\text { perbaikan bagi } \\
\text { guru dengan } \\
\text { melaksanakan } \\
\text { supervisi } \\
\text { kelompok yang } \\
\text { dilakukan oleh } \\
\text { Kepala Sekolah }\end{array}$ \\
\hline
\end{tabular}


Pelaksanaan supervisi klinis merupakan kegiatan yang dilakukan dalam upaya pengendalian mutu di SD Negeri Rowosari pada bagian QI (Quality Improvement). Pelaksanaan supervisi klinis dilakukan oleh kepala sekolah dan peneliti bertindak sebagai pendamping.

\section{KESIMPULAN}

Hasil penelitian dengan analisis Quality Control ditemukan bahwa guru di sekolah tersebut mengalami permasalahan dalam pengajaran, analisis Quality Assurance menghasilkan diagnosis penyebab permasalahan dalam pengajaran, analisis Quality Improvement menghasilkan tindakan yang dilakukan untuk mengatasi masalah yang dihadapi dengan melakukan supervisi klinis. Hasil supervisi klinis menunjukkan adanya peningkatan mutu pengaran yang dilakukan guru pada siklus I dan II, analisis Capacity Building dilakukan untuk memaksimalkan keberhasilan supervisi klinis yang menghasilkan program tindak lanjut yang dapat dilakukan kepala sekolah sebagai pendamping supervisi klinis yaitu melakukan teknik supervisi kelompok.

\section{DAFTAR PUSTAKA}

Achmad, Said Suhil. Profesi Kependidikan. Modul. Online. http://saidsuhil achmad.yolasite.com/resources/Profes i_Kependidikan/Kegiatan\%207_Gena p11.pdf.Akses 24-07-2017, 03:55

Ahmad, M. Analisis Manajemen Mutu Terpadu (TQM) dalam Pelayanan Rumah Sakit (Online) Diakses 28 Februari 2017 dari repository. ung.ac.id/.../ANALISIS-MA NAJEMEN-MUTU-TERPADU, 2017.
Andriani, Dwi Esti. Mutu Guru dan Implikasinya Terhadap Pendidikan. Jurnal Manajemen Pendidikan, 5 (1)

Aspranawa, A. D. Putransu. Memahami Quality Assurance Menjadikan Budaya Mutu Perguruan Tinggi. Jurnal Ekonomi Syariah An-Nisbah. Volume 1 No 2, 2015.

Balqis, P dkk. Kompetensi Pedagogik Guru dalamMeningkatkan Motivasi Belajar Siswa Pada SMPN 3 Ingin Jaya Kabupaten Aceh Besar. Jurnal Administrasi Pendidikan Pascasarjana Universitas Syiah Kuala ISSN 2302-0156pp. 25- 38, 2014.

Korma, I Wayan. Pengaruh Implementasi Pendekatan Supervisi Klinis Terhadap wawasan Kompetensi Pedagogik dan Kualitas Pengelolaan Pembelajaran Para Guru di Gugus IV SD Kecamatan Denpasar Selatan. Jurnal Penelitian Pascasarjana Undiksha. Volume 2 No 2, 2012.

Muslim, S. B. Supervisi pendidikan meningkatkan kualitas profesionalisme guru. Bandung: Alfabeta, 2009.

Pasaribu, Romindo. Manajemen Mutu. Sumatera Utara: Fakultas Ekonomi Universitas HKBP Nommensen, 2015.

Pidarta, Made. Pemikiran tentang supervisi pendidikan. Jakarta: bumi aksara, 2002.

Purwanto, M. N. Administrasi dan supervisi pendidikan (edisi ke 20). Bandung: remaja rosda karya, 2009.

Ratnasari, Jenivia Dwi dkk. Pengembangan Kapasitas (Capacity Building) Kelembagaan Pada Badan Kepegawaian Daerah Kabupaten Jombang. Jurnal Administrasi Publik Universitas Brawijaya. Volume 1 No 3, 2013. 
Satya Widya, Vol. 33, No. 1. Juni 2017: 1-10

Siregar, Yusni. Upaya Meningkatkan Kinerja Guru Melalui Supervisi Klinis di SMPN Kecamatan Medang Deras Kabupaten Batu Bara. Digital Repositori Universitas Negeri Medan, 2016.

Suti, Marsus. Stategi Peningkatan Mutu di Era Otonomi Pendidikan. Jurnal MEDTEK. Volume 3 No 2, 2011. 